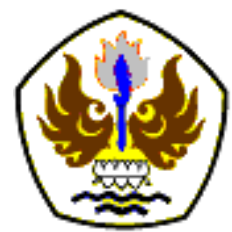

INFOMATEK

Volume 19 Nomor 1 Juni 2017

\title{
PENGARUH NILAI PARAMETER TERHADAP SOLUSI HEURISTIK PADA MODEL VTPTW
}

\author{
Tjutju T. Dimyati \\ Program Studi Teknik Industri \\ Fakultas Teknik - Universitas Pasundan
}

\begin{abstract}
Abstrak: Penentuan rute kendaraan (Vehicle Routing Problem, VRP) merupakan sub persoalan yang sangat penting dari suatu sistem distribusi, sehingga telah mengundang banyak perhatian peneliti untuk menggali berbagai aspek yang terkait dengan persoalan ini. Pada makalah ini dikemukakan suatu metode heuristik untuk menyelesaikan persoalan penentuan rute kendaraan dimana setiap pelanggan menetapkan batas awal dan akhir waktu pengiriman, yang dikenal sebagai Vehicle Routing Problem with Time Windows (VRPTW). Penentuan rute ditujukan tidak hanya untuk meminimumkan total ongkos perjalanan tetapi juga total waktu pelanggan menunggu. Karena metode heuristik yang dibahas melibatkan sejumlah parameter, pada makalah ini juga dilakukan analisis untuk mengetahui pengaruh nilai parameter terhadap solusi yang diperoleh.
\end{abstract}

Kata kunci: Vehicle routing, Time windows, Heuristik

\section{PENDAHULUAN}

\subsection{Latar Belakang}

Bagi perusahaan manufaktur maupun jasa, sistem distribusi/ transportasi memiliki peranan yang sangat penting dalam memberikan pelayanan kepada konsumen. Untuk mengendalikan seluruh aktivitas distribusi dan untuk mengefisienkan penggunaan sumbersumber sistem ini, persoalan yang harus diselesaikan dapat dikelompokkan ke dalam persoalan yang sifatnya strategis, taktis, maupun operasional. Persoalan strategis berkaitan dengan perancangan jaringan fisik,

\footnotetext{
*) tjutjutarliah@unpas.ac.id
}

penentuan lokasi fasilitas, dan pengadaan sumber-sumber yang diperlukan, sedangkan persoalan yang bersifat taktis berkaitan dengan pengalokasian sumber-sumber yang ada untuk memperbaiki kinerja sistem secara keseluruhan. Persoalan pada level operasional berkaitan dengan penentuan rute kendaraan yang melakukan perjalanan dari depot atau gudang ke sejumlah pengecer atau pelanggan, untuk meminimumkan total ongkos perjalanan yang terjadi. Ada dua model persoalan operasional yang banyak dibahas para peneliti, yaitu Travelling Salesman Problem (TSP) dan Vehicle Routing Problem $(V R P)$. 
Pada model VRP, setiap kendaraan dengan kapasitas angkut tertentu dan seragam akan melakukan perjalanan dari depot untuk melakukan pengiriman komoditas ke sejumlah pelanggan dengan tingkat kebutuhan tertentu, dan kembali ke depot. Total kebutuhan yang dilayani setiap rute tidak melebihi kapasitas angkut kendaraan. Setiap pelanggan hanya dilayani oleh satu kendaraan dan setiap rute pengiriman hanya boleh mengunjungi setiap pelanggan satu kali. Tujuannya adalah agar setiap pelanggan terpenuhi kebutuhannya dengan total ongkos yang minimum.

Jika diberlakukan batasan waktu tertentu, baik batasan waktu untuk kendaraan berangkat dari dan kembali ke depot maupun saat paling cepat dan paling lambat untuk kendaraan tiba di masing-masing pelanggan, maka persoalannya dikenal sebagai Vehicle Routing Problem with Time Window (VRPTW). Pada model VRPTW ini yang harus diselesaikan tidak hanya menentukan rute tetapi juga jadwal keberangkatan setiap kendaraan untuk meminimumkan total ongkos perjalanan dan total waktu pelanggan menunggu.

\subsection{Tujuan Pembahasan}

Meskipun persoalan yang melibatkan model VRP banyak dijumpai dalam kehidupan sehari-hari, tetapi untuk memperoleh solusi optimalnya tidaklah mudah karena VRP merupakan persoalan NP-hard (Solomon [1]). $\mathrm{Hal}$ ini telah memotivasi para peneliti mengembangkan berbagai metode heuristik agar dapat digunakan untuk menyelesaikan persoalan-persoalan dalam kehidupan seharihari, yang pada umumnya berukuran besar (Solomon dkk. [2]), (Solomon dkk. [3]), (Thangiah dkk. [4]), (loannou dkk. [5]).

Pada makalah ini dibahas suatu metode heuristik untuk menyelesaikan persoalan VRPTW, dengan menggunakan metoda Insertion Heuristik-I1 sebagai dasar pengembangan. Metoda Insertion Heuristik-I1 sendiri pada dasarnya merupakan pengembangan dari metoda Saving Heuristic yang dikembangkan oleh Clarke dan Wright untuk persoalan VRP klasik (Ghiani dkk. [7]). Bagian 3 dari makalah ini menguraikan formulasi persoalan yang akan diselesaikan serta model matematisnya, sedang metode heuristik yang dibahas disajikan pada bagian 4. Untuk memudahkan pemahaman terhadap metode yang dibahas, pada bagian 5 disajikan suatu ilustrasi numerik lengkap dengan hasil perhitungan. Analisis terhadap nilai parameter yang digunakan dalam proses pencarian solusi disajikan pada bagian 6. Sebagai penutup dari seluruh pembahasan, pada bagian 7 dikemukakan beberapa hal yang berkaitan dengan metoda heuristik yang dibahas. 


\subsection{Formulasi Persoalan}

Untuk menjelaskan model VRPTW, perhatikan suatu graph $(N, A)$. Set node $N$ terdiri dari suatu set pelanggan yang dinyatakan sebagai $C$, dimana node 0 dan node $n+1$ adalah depot. Set $\operatorname{arc} A$ menyatakan hubungan di antara node satu dengan node yang lain. Tidak ada arc yang berakhir di node 0 dan tidak ada arc yang berawal dari node $n+1$. Setiap rute akan berawal dari node 0 dan akan berakhir di node $n+1$. Setiap $\operatorname{arc}(i, j) \in A$ ditandai dengan ongkos $C_{i j}$ dan waktu tempuh $t_{i j}$. Karena besarnya ongkos dianggap proporsional terhadap jarak dan waktu tempuh maka besarnya unit ongkos bisa dinyatakan sama dengan 1. Setiap pelanggan berkaitan dengan kebutuhan $d_{i}$ dan waktu pelayanan $t_{i}, i \in C$. Set kendaraan dinyatakan sebagai $V$ dimana setiap kendaraan memiliki kapasitas angkut yang seragam, yaitu $q$. Pelayanan di setiap pelanggan harus dilaksanakan dalam interval waktu $\left[a_{i}, b_{i}\right], i \in C$. Setiap kendaraan harus meninggalkan depot dalam interval waktu $\left[a_{0}\right.$, $b_{0}$ ] dan harus kembali ke depot dalam interval waktu $\left[a_{n+1}, b_{n+1}\right]$. Kendaraan yang datang di pelanggan sebelum awal time window harus menunggu hingga pelayanan dapat dimulai, tetapi tidak boleh datang setelah batas atas time window.

Untuk memformulasikan model matematis VRPTW digunakan dua variabel berikut:
$X_{i j k}=1$ jika kendaraan $k$ melakukan perjalanan dari node $i$ ke $j \quad(\forall(i, j) \in$ $A, \forall k \in V$ $=0$ jika tidak

$S_{i k}(\forall i \in N, \forall k \in V)$ menyatakan saat kendaraan $k$ memulai pelayanan di pelanggan $i(i \in C)$

Dalam hal ini dapat diasumsikan $S_{0 k}=0 \quad \forall k$. $S_{n+1, k}$ menyatakan saat kepulangan kendaraan $k$ di depot. Model matematis VRPTW dapat diformulasikan sebagai berikut:

$$
\operatorname{Min} \sum_{k \in V} \sum_{(i, j) \in A} C_{i j} X_{i j k}
$$

dengan pembatas:

$$
\begin{array}{ll}
\sum_{k \in V} \sum_{j \in N} X_{i j k}=1 & \forall i \in C \\
\sum_{i \in C} d_{i} \sum_{j \in N} X_{i j k} \leq q & \forall k \in V \\
\sum_{j \in N} X_{0 j k}=1 & \forall k \in V \\
\sum_{i \in N} X_{i h k}-\sum_{j \in N} X_{h j k}=0 & (3) \\
\sum_{i \in N} X_{i, n+1, k}=1 & \forall k \in V, \forall k \in V \\
X_{i j k}\left(S_{i k}+t_{i}+t_{i j}-S_{j k}\right) \leq 0 \\
a_{i} \leq S_{i k} \leq b_{i} & \forall(5) \\
X_{i j k} \in\{0,1\} & \forall k \in V, \forall k \in V
\end{array}
$$

Fungsi tujuan (1) menyatakan bahwa total ongkos harus diminimumkan. Pembatas (2) 
menyatakan bahwa setiap pelanggan hanya dilayani oleh satu kendaraan, sedang pembatas (3) menyatakan setiap kendaraan hanya akan melayani konsumen sebatas kapasitasnya. Pembatas (4), (5), dan (6) menyatakan bahwa setiap kendaraan $k$ akan berangkat dari depot, meninggalkan node $h$, $(h \in C)$ jika kendaraan itu memasuki node $h$, dan akan kembali ke depot. $\operatorname{Arc}(0, n+1)$ dimasukkan ke dalam network untuk mengikut sertakan perjalanan awal dari depot dan perjalanan kembali ke depot. Pembatas (7) menyatakan bahwa jika kendaraan $k$ melakukan perjalanan dari $i$ ke $j$ maka kendaraan tesebut akan tiba di node $j$ setelah $S_{i k}+t_{i}+t_{i j}$. Pembatas (8) menyatakan setiap kendaraan $k$ akan tiba di pelanggan $i$ dalam batas time window pelanggan tersebut, sedangkan pembatas (9) adalah pembatas integralitas.

\section{METODE PENYELESAIAN}

\subsection{Metode Heuristik}

Metode heuristik yang dibahas pada makalah ini pada dasarnya adalah suatu prosedur pembentukan rute yang dilakukan dengan cara memilih pelanggan (dinyatakan sebagai node) yang akan disisipkan ke dalam suatu rute yang sudah ada. Proses penyisipan dilakukan hingga rute yang bersangkutan dinyatakan "penuh", baik berdasarkan kapasitas kendaraan maupun jadwal waktu pelayanan di masing-masing pelanggan.
Tujuannya adalah untuk membentuk satu atau beberapa rute pelayanan dengan total ongkos perjalanan yang minimum. Diasumsikan besarnya ongkos proporsional terhadap jarak dan waktu tempuh.

Proses pemilihan dan penyisipan node ke dalam rute dilakukan sebagai berikut:

Langkah 0 (Inisialisasi)

- Nyatakan seluruh node (tidak termasuk depot) yang belum masuk ke dalam rute sebagai node bebas

- Pilih satu node bebas untuk dijadikan node awal dari rute yang akan dibentuk, nyatakan node tersebut sebagai node i. Pemilihan node awal bisa didasarkan pada jarak node terhadap depot atau berdasarkan jadwal waktu pelayanan.

- Tetapkan rute awal sebagai $R=\{0, i$, $n+1\}$ dengan 0 dan $n+1$ adalah depot

Langkah 1 (Penetapan nilai parameter)

- Nyatakan node bebas yang dipertimbangkan untuk disisipkan sebagai node $u$

- Tetapkan nilai parameter $\mu$ yaitu bobot yang diberikan terhadap penghematan jarak yang diperoleh jika dilakukan penyisipan node $u$. $\mu \geq 0$

- Tetapkan nilai parameter $\alpha 1$ yaitu bobot yang diberikan terhadap total jarak yang terjadi akibat penyisipan node $\mathrm{u}$ dan parameter $\alpha 2$ yaitu bobot 
yang diberikan terhadap perubahan waktu pelayanan akibat penyisipan node $u . \alpha 1+\alpha 2=1$

- Tetapkan nilai parameter $\lambda$ yaitu bobot yang diberikan bagi ongkos perjalanan dari depot ke node $u$ jika node $u$ tidak disisipkan ke dalam rute. $\lambda \geq 0$

Langkah 2 (Pemilihan dan penyisipan node)

- Nyatakan rute saat ini sebagai $R=\{0$, i1 , ... j \} (0 dan j adalah depot)

- Untuk setiap node bebas $u$, hitung total tambahan jarak yang terjadi jika node $u$ disisipkan, dengan menggunakan formula

$$
Z_{11}(i, u, j)=d_{i u}+d_{u j}-\mu d_{i j} ; \mu \geq 0
$$

○ diu, duj, dan dij masing-masing adalah jarak antara node i dengan node $\mathrm{u}$, node $\mathrm{u}$ dengan node $\mathrm{j}$, dan node i dengan node $\mathrm{j}$

- Hitung tambahan waktu untuk kendaraan tiba dan memulai pelayanan di node i jika node $u$ disisipkan, dengan menggunakan formula

$$
Z_{12}(i, u, j)=t_{0 u}+t_{u}+t_{u i}-t_{0 i}
$$

- $t_{o u}, t_{u i}$, dan $t_{0 i}$ adalah waktu tempuh dari depot ke node $u$, dari node $u$ ke node $i$, dan dari depot ke node $i$, sedang $t_{u}$ adalah waktu pelayanan di node $u$

- Hitung besarnya ongkos penyisipan yang besarnya proporsional terhadap tambahan jarak dan tambahan waktu tempuh untuk tiba di node $i$ jika node $u$ disisipkan, dengan menggunakan formula

$$
\begin{gathered}
Z_{1}(i, u, j)=\alpha_{1} Z_{11}(i, u, j)+\alpha_{2} Z_{12} \\
(i, u, j) ; \alpha_{1} \geq 0 ; \alpha_{2} \geq 0 ; \alpha_{1}+\alpha_{2}=1
\end{gathered}
$$

- Sisipkan node bebas $u$ yang memiliki nilai $Z_{1}(i, u, j)$ minimum ke dalam rute, di antara node $i$ dan node $j$ yang sudah ada

- Jika kapasitas kendaraan dan batas waktu pelayanan masih memungkinkan, lakukan penyisipan berikutnya berdasarkan nilai $Z_{2}(i, u, j)$ maksimum, dimana

$$
\begin{aligned}
& Z_{2}(i, u, j)=\lambda d_{O u}-Z_{1}(i, u, j) ; \\
& \lambda \geq 0
\end{aligned}
$$

menyatakan selisih antara ongkos yang terjadi jika node $u$ ditempuh langsung dari depot dengan ongkos yang terjadi jika node $u$ disisipkan ke dalam rute

Langkah 3 (Pengulangan)

Jika masih ada node bebas, ulangi langkah 2 hingga seluruh node masuk ke dalam rute.

Langkah 4 (Perbaikan solusi)

Untuk setiap rute yang telah terbentuk, lakukan perubahan posisi node atau urutan pelanggan yang dikunjungi, untuk memperoleh total jarak dan total waktu menunggu yang minimum. 


\subsection{Ilustrasi Numerik}

Misalkan ada suatu depot yang melayani pengiriman suatu komoditas ke 12 pelanggan. Pada Tabel 1 disajikan data tingkat kebutuhan komoditas (dalam unit) dan jadwal waktu pelayanan di masing-masing pelanggan. Data jarak (dalam $\mathrm{Km}$ ) serta waktu tempuh (dalam menit) dari depot ke pelanggan dan antar pelanggan adalah seperti pada Tabel 2 . Kapasitas setiap kendaraan adalah 30 unit, sedangkan lama waktu pelayanan di setiap pelanggan adalah 15 menit. Setiap kendaraan harus meninggalkan depot pada pukul 9:00 dan harus sudah kembali ke depot pada pukul 12:00.

Tabel 1

Data tingkat kebutuhan dan jadwal pelayanan

\begin{tabular}{|c|c|c|c|c|c|c|c|c|c|c|c|c|}
\cline { 2 - 13 } \multicolumn{1}{c|}{} & \multicolumn{10}{c|}{ Pelanggan (node) } \\
\cline { 2 - 13 } & $\mathbf{1}$ & $\mathbf{2}$ & $\mathbf{3}$ & $\mathbf{4}$ & $\mathbf{5}$ & $\mathbf{6}$ & $\mathbf{7}$ & $\mathbf{8}$ & $\mathbf{9}$ & $\mathbf{1 0}$ & $\mathbf{1 1}$ & $\mathbf{1 2}$ \\
\hline $\begin{array}{c}\text { Tingkat } \\
\text { Kebutuhan }\end{array}$ & 7 & 8 & 6 & 8 & 6 & 7 & 8 & 7 & 6 & 7 & 5 & 9 \\
\hline $\begin{array}{c}\text { Batas Awal } \\
\text { Pelayanan }\end{array}$ & $9: 00$ & $9: 00$ & $9: 00$ & $11: 00$ & $9: 00$ & $11: 00$ & $9: 00$ & $10: 00$ & $9: 00$ & $9: 00$ & $10: 00$ & $10: 00$ \\
\hline $\begin{array}{c}\text { Batas Akhir } \\
\text { Pelayanan }\end{array}$ & $11: 30$ & $12: 30$ & $12: 30$ & $12: 30$ & $12: 30$ & $12: 30$ & $12: 30$ & $12: 30$ & $10: 30$ & $11: 15$ & $12: 45$ & $12: 30$ \\
\hline
\end{tabular}

Tabel 2

Data jarak (di bawah diagonal) dan waktu tempuh (di atas diagonal)

\begin{tabular}{|c|c|c|c|c|c|c|c|c|c|c|c|c|c|}
\hline Node & $\mathbf{0}$ & $\mathbf{1}$ & $\mathbf{2}$ & $\mathbf{3}$ & $\mathbf{4}$ & $\mathbf{5}$ & $\mathbf{6}$ & $\mathbf{7}$ & $\mathbf{8}$ & $\mathbf{9}$ & $\mathbf{1 0}$ & $\mathbf{1 1}$ & $\mathbf{1 2}$ \\
\hline $\mathbf{0}$ & 0 & 30.0 & 31.0 & 30.0 & 30.0 & 27.0 & 23.0 & 25.0 & 30.0 & 41.0 & 31.0 & 24.0 & 33.0 \\
\hline $\mathbf{1}$ & 9.8 & 0 & 14.0 & 18.0 & 5.0 & 16.0 & 28.0 & 29.0 & 12.0 & 13.0 & 13.0 & 28.0 & 6.0 \\
\hline $\mathbf{2}$ & 10.1 & 4.6 & 0 & 7.0 & 11.0 & 5.0 & 21.0 & 20.0 & 5.0 & 15.0 & 6.0 & 24.0 & 13.0 \\
\hline $\mathbf{3}$ & 9.8 & 6 & 2.2 & 0 & 15.0 & 5.0 & 21.0 & 20.0 & 9.0 & 23.0 & 12.0 & 24.0 & 17.0 \\
\hline $\mathbf{4}$ & 9.9 & 0.9 & 3.6 & 4.9 & 0 & 16.0 & 28.0 & 29.0 & 12.0 & 12.0 & 13.0 & 28.0 & 6.0 \\
\hline $\mathbf{5}$ & 8.9 & 5.3 & 0.7 & 1.4 & 5.3 & 0 & 18.0 & 17.0 & 8.0 & 19.0 & 10.0 & 21.0 & 16.0 \\
\hline $\mathbf{6}$ & 7.6 & 9.1 & 7 & 7 & 9.1 & 5.8 & 0 & 5.0 & 21.0 & 32.0 & 23.0 & 5.0 & 31.0 \\
\hline $\mathbf{7}$ & 8.1 & 9.5 & 6.5 & 6.5 & 9.5 & 5.4 & 0.6 & 0 & 23.0 & 34.0 & 24.0 & 5.0 & 32.0 \\
\hline $\mathbf{8}$ & 9.8 & 3.9 & 1.4 & 2.9 & 3.9 & 2.6 & 7 & 7.5 & 0 & 11.0 & 5.0 & 28.0 & 8.0 \\
\hline $\mathbf{9}$ & 13.4 & 4.3 & 4.9 & 7.5 & 3.7 & 6.1 & 10.5 & 11.08 & 3.5 & 0 & 10.0 & 35.0 & 10.0 \\
\hline $\mathbf{1 0}$ & 10.1 & 4.3 & 1.9 & 3.8 & 4.3 & 3.1 & 7.5 & 8 & 0.5 & 3.3 & 0 & 30.0 & 7.0 \\
\hline $\mathbf{1 1}$ & 7.8 & 9.2 & 7.9 & 7.7 & 9.2 & 6.7 & 0.7 & 0.9 & 9.3 & 11.5 & 9.7 & 0 & 33.0 \\
\hline $\mathbf{1 2}$ & 10.9 & 1.9 & 4.1 & 5.6 & 1.7 & 5.2 & 10.1 & 10.6 & 2.6 & 3.1 & 2.1 & 10.9 & 0 \\
\hline
\end{tabular}

Untuk menyelesaikan persoalan di atas ditetapkan nilai $\mu=1 ; \alpha_{1}=\alpha_{2}=0.5$; dan $\lambda=$ 1. Dari data di atas diketahui bahwa total kebutuhan di seluruh pelanggan adalah 84 unit. Karena kapasitas kendaraan adalah 30 unit maka diperlukan 3 unit kendaraan, yang berarti juga akan terbentuk tiga rute yang berasal dan berakhir di depot. 
Iterasi 1:

Sebagai node awal pada rute $R_{1}$ dipilih node 9 yang merupakan pelanggan dengan batas awal dan batas akhir pelayanan paling cepat, sehingga $R_{1}=\{0,9,0\}$. Karena kapasitas kendaraan dan jadwal waktu pelayanan masih memungkinkan maka selanjutnya dilakukan pemilihan node $u$ yang akan disisipkan. Hasil perhitungan disajikan pada Tabel 3.

Tabel 3

Hasil perhitungan untuk iterasi 1

\begin{tabular}{|c|c|c|c|c|c|c|c|c|c|c|c|}
\hline $\mathbf{i}$ & $\mathbf{u}$ & $\mathbf{d}(\mathbf{i}, \mathbf{u})$ & $\mathbf{d}(\mathbf{u}, \mathbf{0})$ & $\mathbf{d}(\mathbf{i}, \mathbf{0})$ & $\mathbf{Z 1 1}$ & $\mathbf{t}(\mathbf{0}, \mathbf{u})$ & $\mathbf{t}(\mathbf{u}, \mathbf{i})$ & $\mathbf{t}(\mathbf{0}, \mathbf{i})$ & $\mathbf{Z 1 2}$ & $\mathbf{Z 1}$ & $\mathbf{Z 2}$ \\
\hline 9 & 1 & 4.3 & 9.8 & 13.4 & 0.7 & 30.0 & 13.0 & 41.0 & 17 & 8.85 & 0.95 \\
\hline & 2 & 4.9 & 10.1 & 13.4 & 1.6 & 31.0 & 15.0 & 41.0 & 20 & 10.8 & -0.7 \\
\hline & 3 & 7.5 & 9.8 & 13.4 & 3.9 & 30.0 & 23.0 & 41.0 & 27 & 15.45 & -5.65 \\
\hline & 4 & 3.7 & 9.9 & 13.4 & 0.2 & 30.0 & 12.0 & 41.0 & 16 & 8.1 & 1.8 \\
\hline & 5 & 6.1 & 8.9 & 13.4 & 1.6 & 27.0 & 19.0 & 41.0 & 20 & 10.8 & -1.9 \\
\hline & 6 & 10.5 & 7.6 & 13.4 & 4.7 & 23.0 & 32.0 & 41.0 & 29 & 16.85 & -9.25 \\
\hline & 7 & 11.08 & 8.1 & 13.4 & 5.78 & 25.0 & 34.0 & 41.0 & 33 & 19.39 & -11.29 \\
\hline & 8 & 3.5 & 9.8 & 13.4 & -0.1 & 30.0 & 11.0 & 41.0 & 15 & 7.45 & 2.35 \\
\hline & 10 & 3.3 & 10.1 & 13.4 & 0 & 31.0 & 10.0 & 41.0 & 15 & 7.5 & 2.6 \\
\hline & 11 & 11.5 & 7.8 & 13.4 & 5.9 & 24.0 & 35.0 & 41.0 & 33 & 19.45 & -11.65 \\
\hline & 12 & 3.1 & 10.9 & 13.4 & 0.6 & 33.0 & 10.0 & 41.0 & 17 & 8.8 & 2.1 \\
\hline
\end{tabular}

Berdasarkan nilai $Z_{1}$ maka node yang harus disisipkan di antara node 9 dan depot adalah node 8 sehingga diperoleh rute $R_{1}=\{0,9,8$, 0\}. Proses penyisipan masih dapat dilakukan dengan memperhatikan nilai $Z_{2}$ sehingga akhirnya diperoleh rute $R_{1}=\{0,9,8,10,12$, 0\}. Resume hasil perhitungan untuk rute $R_{1}$ disajikan pada Tabel 4.

Tabel 4

Resume hasil perhitungan iterasi 1

\begin{tabular}{|l|c|c|c|c|c|}
\hline \multicolumn{1}{|c|}{ Node } & Tiba & Berangkat & Waktu menunggu & Kumulatif unit & Kumulatif jarak \\
\hline Depot & & $9: 00$ & & & \\
\hline Pelanggan 9 & $9: 41$ & $9: 56$ & - & 6 & 13.4 \\
\hline Pelanggan 8 & $10: 07$ & $10: 22$ & - & 13 & 16.9 \\
\hline Pelanggan 10 & $10: 27$ & $10: 42$ & - & 20 & 17.4 \\
\hline Pelanggan 12 & $10: 49$ & $11: 04$ & - & 29 & 19.5 \\
\hline Depot & $11: 37$ & & & & 30.4 \\
\hline
\end{tabular}

Dengan cara yang sama dilakukan perhitungan untuk memperoleh rute kedua dan ketiga sehingga diperoleh $R_{2}=\{0,1,4,5$,
2, 0$\}$ dan $R_{3}=\{0,3,6,7,11,0\}$. Kedua rute ini tidak fisibel karena menyebabkan kendaraan tiba di depot lebih dari pukul 12:00. Hal ini 
terjadi karena dari rute $R_{2}$ diperoleh waktu tunggu selama 70 menit di pelanggan 4, sedangkan dari rute $R_{3}$ diperoleh waktu tunggu selama 54 menit di pelanggan 6 . Karena itu maka dilakukan evaluasi terhadap urutan pelayanan pelanggan untuk memperoleh rute baru yang fisibel. Hasil yang diperoleh adalah $R_{2}=\{0,1,5,2,4,0\}$ dan $R_{3}$ $=\{0,3,7,11,6,0\}$. Resume hasil perhitungan disajikan pada Tabel 5 dan Tabel 6.

Tabel 5

Resume hasil perhitungan iterasi 2

\begin{tabular}{|l|c|c|c|c|c|}
\hline \multicolumn{1}{|c|}{ Node } & Tiba & Berangkat & Waktu menunggu & Kumulatif unit & Kumulatif jarak \\
\hline Depot & & $9: 00$ & & & \\
\hline Pelanggan 1 & $9: 30$ & $9: 45$ & - & 7 & 9.8 \\
\hline Pelanggan 5 & $10: 01$ & $10: 16$ & - & 13 & 15.1 \\
\hline Pelanggan 2 & $10: 21$ & $10: 37$ & - & 21 & 15.8 \\
\hline Pelanggan 4 & $10: 48$ & $11: 15$ & 12 menit & 29 & 19.4 \\
\hline Depot & $11: 45$ & & & & 29.3 \\
\hline
\end{tabular}

Tabel 6

Resume hasil perhitungan iterasi 3

\begin{tabular}{|l|c|c|c|c|c|}
\hline \multicolumn{1}{|c|}{ Node } & Tiba & Berangkat & Waktu menunggu & Kumulatif unit & Kumulatif jarak \\
\hline Depot & & $9: 00$ & & & \\
\hline Pelanggan 3 & $9: 30$ & $9: 45$ & - & 6 & 9.8 \\
\hline Pelanggan 7 & $10: 06$ & $10: 21$ & - & 14 & 16.3 \\
\hline Pelanggan 11 & $10: 26$ & $10: 41$ & - & 19 & 17.2 \\
\hline Pelanggan 6 & $10: 46$ & $11: 15$ & 14 menit & 26 & 17.9 \\
\hline Depot & $11: 38$ & & & & 25.5 \\
\hline
\end{tabular}

\section{ANALISIS NILAI PARAMETER}

Metode heuristik yang dibahas pada makalah ini menggunakan formula yang sederhana sehingga dapat dengan mudah diselesaikan secara manual, meskipun untuk persoalan yang berukuran besar. Karena solusi yang diperoleh akan ditentukan oleh nilai parameter-parameter $\mu, \alpha_{1}, \alpha_{2}$, dan $\lambda$ yang digunakan, maka perlu dilakukan analisis terhadap nilai parameter-parameter tersebut untuk memperoleh solusi terbaik (berdasarkan kriteria yang ditetapkan).
Analisis dilakukan dengan skenario sebagai berikut:

1. Perubahan nilai parameter

- Nilai parameter $\mu$ akan dirubah mulai dari $\mu=1$ hingga $\mu=9$ dengan perubahan nilai sebesar 1

- Nilai parameter $\alpha_{1}$ akan dirubah mulai dari $\alpha_{1}=0,1$ hingga $\alpha_{1}=$ 0,9 dengan perubahan sebesar $0,1\left(\alpha_{2}=1-\alpha_{1}\right)$ 
- $\quad$ ilai parameter $\lambda$ akan dirubah mulai dari $\lambda=1$ hingga $\lambda=9$ dengan perubahan sebesar 1

2. Pengulangan perhitungan 1

- Perhitungan diawali dengan menetapkan $\mu=1 ; \alpha_{1}=0,1 ; \alpha_{2}$ $=1-\alpha_{1}$ dan $\lambda=1$

- Ulangi perhitungan dengan $\mu=$ $1 ; \alpha_{1}=0,2 ; \alpha_{2}=1-\alpha_{1}$ dan $\lambda=2$ kemudian dengan $\mu=1 ; \alpha_{1}=$ 0,$3 ; \alpha_{2}=1-\alpha_{1}$ dan $\lambda=3$ dan seterusnya sehingga terjadi pengulangan sebanyak 9 kali

- Ulangi perhitungan dan pengulangan dengan $\mu=2$ hingga $\mu=9$ sehingga total diperoleh 81 hasil perhitungan

3. Pengulangan perhitungan 2

- Lakukan proses yang sama diawali dengan menetapkan $\alpha_{1}$ $=0,1 ; \alpha_{2}=1-\alpha_{1}$ tetapi dengan $\mu$ $=1$ dan $\lambda=1$ hingga $\mu=9$ dan $\lambda=9$

- Ulangi perhitungan dan pengulangan dengan $\alpha_{1}=0,2$ hingga $\alpha_{1}=0,9$ sehingga total diperoleh 81 hasil perhitungan

4. Pengulangan perhitungan 3

- Lakukan proses yang sama diawali dengan menetapkan nilai $\lambda=1$; tetapi dengan $\alpha_{1}=$ 0,$1 ; \alpha_{2}=1-\alpha_{1}$ dan $\mu=1$ hingga $\alpha_{1}=0,9 ; \alpha_{2}=1-\alpha_{1}$ dan $\mu=9$

- Ulangi perhitungan dan pengulangan dengan $\lambda=2$ hingga $\lambda=9$ sehingga total diperoleh 81 hasil perhitungan

Untuk nilai $\mu=1$ dengan $\alpha_{1}, \alpha_{2}$, dan $\lambda$ berubah hasil perhitungan memberikan total jarak tempuh yang berbeda seperti ditunjukkan pada Gambar 1.

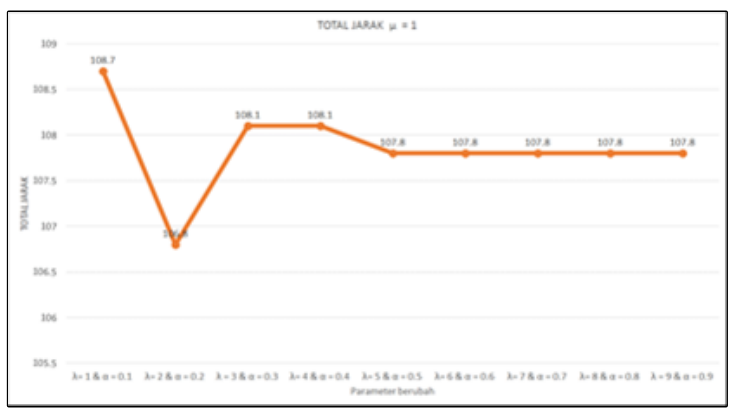

Gambar 1

Hasil perhitungan untuk $\mu=1$ dengan $\alpha_{1}, \alpha_{2}$, dan $\lambda$ berubah

Gambar di atas menunjukkan bahwa untuk parameter $\mu=1$, total jarak terpendek $=106,8$ diperoleh saat nilai $\alpha_{1}=0,2$ dan $\lambda=2$

Adapun hasil keseluruhan dari pengulangan perhitungan 1 ( $\mu$ tetap, $\alpha_{1}, \alpha_{2}$, dan $\lambda$ berubah) ditunjukkan pada Tabel 7 dan Gambar 2.

\section{Tabel 7}

Resume Hasil Perhitungan untuk $\mu$ tetap, $\alpha_{1}, \alpha_{2}$, dan $\lambda$ berubah

\begin{tabular}{|c|c|c|c|c|c|}
\hline \multirow{2}{*}{ NO } & \multicolumn{4}{|c|}{ perubahan Parameter } & \multirow{2}{*}{ total jarak } \\
\hline & $\mu$ & $\alpha \_1$ & $\alpha \_2$ & $\lambda$ & \\
\hline 1 & 1 & 0.2 & 0.8 & 2 & $106.8 \mathrm{~km}$ \\
\hline 2 & 2 & 0.2 & 0.8 & 2 & $106.8 \mathrm{~km}$ \\
\hline 3 & 3 & 0.2 & 0.8 & 2 & $106.8 \mathrm{~km}$ \\
\hline 4 & 4 & 0.2 & 0.8 & 2 & $106.8 \mathrm{~km}$ \\
\hline 5 & 5 & 0.2 & 0.8 & 2 & $106.8 \mathrm{~km}$ \\
\hline 6 & 6 & 0.2 & 0.8 & 2 & $106.8 \mathrm{~km}$ \\
\hline 7 & 7 & 0.2 & 0.8 & 2 & $106.8 \mathrm{~km}$ \\
\hline 8 & 8 & 0.2 & 0.8 & 2 & $106.8 \mathrm{~km}$ \\
\hline 9 & 9 & 0.2 & 0.8 & 2 & $106.8 \mathrm{~km}$ \\
\hline
\end{tabular}




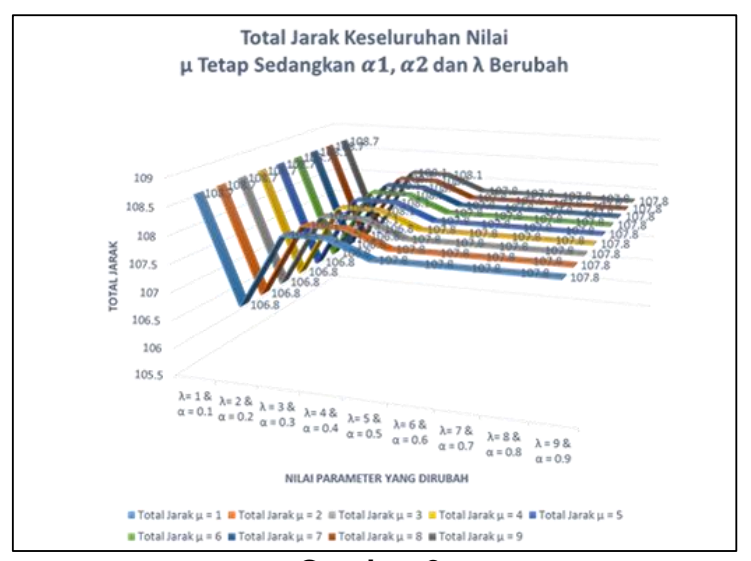

Gambar 2

Gambar 2. Grafik perbandingan hasil perhitungan untuk $\mu$ tetap, $\alpha_{1}, \alpha_{2}$, dan $\lambda$ berubah

Rute yang terbentuk adalah:

$R_{1}=\{0,9,8,10,12,0\}, R_{2}=\{0,1,2,5$, $0\}, R_{3}=\{0,3,6,7,0\}$, dan $R_{4}=\{0,11$, $4,0\}$.

Hasil keseluruhan pengulangan perhitungan 2 ( $\alpha_{1}, \alpha_{2}$ tetap, $\mu$ dan $\lambda$ berubah) ditunjukkan pada Tabel 8 dan Gambar 3.

\section{Tabel 8}

Resume Hasil Perhitungan untuk $\alpha_{1}, \alpha_{2}$ tetap, $\mu$ dan $\lambda$ berubah

\begin{tabular}{|c|c|c|c|c|c|}
\hline \multirow{2}{*}{ NO } & \multicolumn{4}{|c|}{ perubahan Parameter } & \multirow{2}{*}{ total jarak } \\
\cline { 2 - 6 } & $\mu$ & $\alpha_{1}$ & $\alpha_{2}$ & $\lambda$ & \\
\hline 1 & 2 & 0.1 & 0.9 & 2 & $106.8 \mathrm{~km}$ \\
\hline 2 & 1 & 0.2 & 0.8 & 1 & $106.8 \mathrm{~km}$ \\
\hline 3 & 1 & 0.6 & 0.4 & 1 & $106.8 \mathrm{~km}$ \\
\hline 4 & 1 & 0.7 & 0.3 & 1 & $106.8 \mathrm{~km}$ \\
\hline 5 & 1 & 0.8 & 0.2 & 1 & $106.8 \mathrm{~km}$ \\
\hline
\end{tabular}

Rute yang terbentuk adalah:

$R_{1}=\{0,9,8,10,12,0\}, R_{2}=\{0,1,2,5$, $0\}, R_{3}=\{0,3,6,7,0\}$, dan $R_{4}=\{0,11$, $4,0\}$.

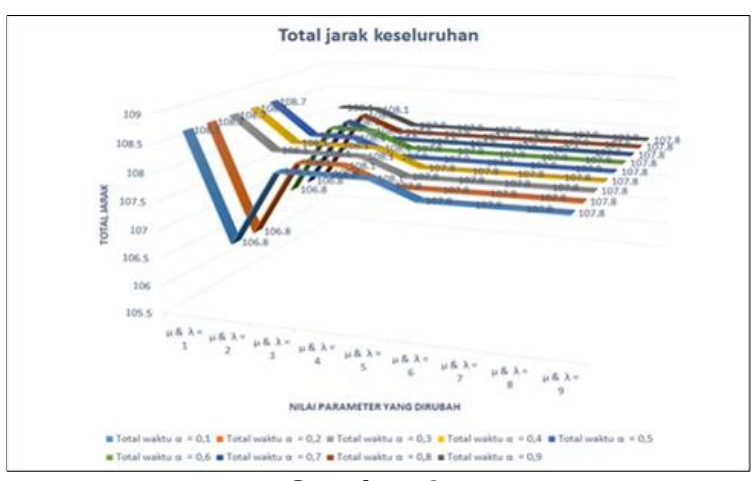

\section{Gambar 3}

Grafik perbandingan hasil perhitungan untuk $\alpha_{1}, \alpha_{2}$ tetap, $\mu$ dan $\lambda$ berubah

Hasil keseluruhan pengulangan perhitungan 3 ( $\alpha_{1}, \alpha_{2}$ tetap, $\mu$ dan $\lambda$ berubah) ditunjukkan pada Tabel 9 dan Gambar 4.

\section{Tabel 9}

Resume Hasil Perhitungan untuk $\lambda$ tetap, $\mu$ dan $\alpha_{1}$, $\alpha_{2}$ berubah

\begin{tabular}{|c|c|c|c|c|c|}
\hline \multirow{2}{*}{ NO } & \multicolumn{4}{|c|}{ perubahan Parameter } & \multirow{2}{*}{ total jarak } \\
\hline & $\mu$ & $\alpha \_1$ & $\alpha \_z$ & $\lambda$ & \\
\hline 1 & 6 & 0.6 & 0.4 & 1 & $106.8 \mathrm{~km}$ \\
\hline 2 & 7 & 0.7 & 0.3 & 1 & $106.8 \mathrm{~km}$ \\
\hline 3 & 8 & 0.8 & 0.2 & 1 & $106.8 \mathrm{~km}$ \\
\hline 4 & 9 & 0.9 & 0.1 & 1 & $106.8 \mathrm{~km}$ \\
\hline 5 & 1 & 0.1 & 0.9 & 2 & $106.8 \mathrm{~km}$ \\
\hline 6 & 2 & 0.2 & 0.8 & 2 & $106.8 \mathrm{~km}$ \\
\hline 7 & 3 & 0.3 & 0.7 & 2 & $106.8 \mathrm{~km}$ \\
\hline 8 & 4 & 0.4 & 0.6 & 2 & $106.8 \mathrm{~km}$ \\
\hline 9 & 5 & 0.5 & 0.5 & 2 & $106.8 \mathrm{~km}$ \\
\hline 10 & 6 & 0.6 & 0.4 & 2 & $106.8 \mathrm{~km}$ \\
\hline 11 & 7 & 0.7 & 0.3 & 2 & $106.8 \mathrm{~km}$ \\
\hline 12 & 8 & 0.8 & 0.2 & 2 & $106.8 \mathrm{~km}$ \\
\hline 13 & 9 & 0.9 & 0.1 & 2 & $106.8 \mathrm{~km}$ \\
\hline 14 & 1 & 0.1 & 0.9 & 3 & $106.8 \mathrm{~km}$ \\
\hline 15 & 2 & 0.2 & 0.8 & 3 & $106.8 \mathrm{~km}$ \\
\hline 16 & 3 & 0.3 & 0.7 & 3 & $106.8 \mathrm{~km}$ \\
\hline 17 & 4 & 0.4 & 0.6 & 3 & $106.8 \mathrm{~km}$ \\
\hline 18 & 5 & 0.5 & 0.5 & 3 & $106.8 \mathrm{~km}$ \\
\hline 19 & 6 & 0.6 & 0.4 & 3 & $106.8 \mathrm{~km}$ \\
\hline 20 & 1 & 0.1 & 0.9 & 4 & $106.8 \mathrm{~km}$ \\
\hline 21 & 2 & 0.2 & 0.8 & 4 & $106.8 \mathrm{~km}$ \\
\hline 22 & 3 & 0.3 & 0.7 & 4 & $106.8 \mathrm{~km}$ \\
\hline 23 & 4 & 0.4 & 0.6 & 4 & $106.8 \mathrm{~km}$ \\
\hline 24 & 1 & 0.1 & 0.9 & 5 & $106.8 \mathrm{~km}$ \\
\hline
\end{tabular}


$R_{1}=\{0,9,8,10,12,0\}, R_{2}=\{0,1,2,5,0\}, R_{3}$ $=\{0,3,6,7,0\}$, dan $R_{4}=\{0,11,4,0\}$.

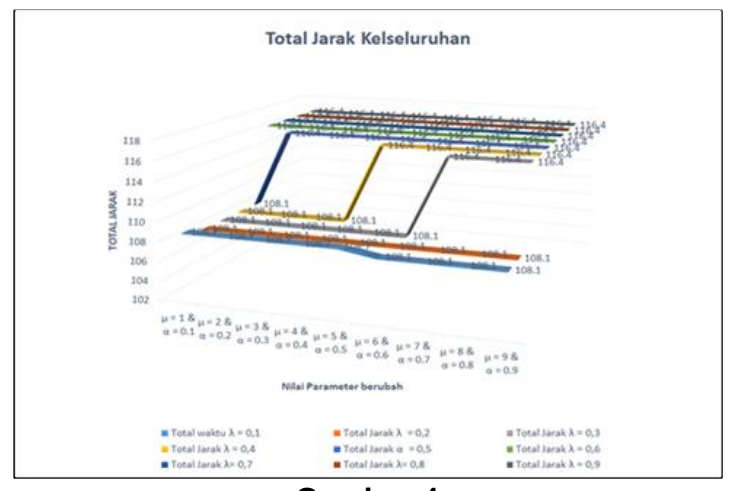

Gambar 4

Grafik perbandingan hasil perhitungan untuk $\lambda$ tetap, $\mu$ dan $\alpha_{1}, \alpha_{2}$ berubah

\section{PENUTUP}

Pendisribusian suatu komoditas dari depot atau gudang ke sejumlah agen atau pelanggan merupakan permasalahan yang umum dijumpai dalam kehidupan sehari-hari, sekaligus merupakan permasalahan yang tidak mudah untuk diselesaikan dengan menggunakan model optimasi. Karena itu perlu dikembangkan suatu metode penyelesaian yang sederhana dan mudah dilakukan, tetapi dapat memberikan solusi yang cukup baik dan mendekati solusi optimalnya.

Metode heuristik yang dibahas pada makalah ini mengasumsikan bahwa ongkos bersifat proporsional terhadap jarak dan waktu tempuh. Apabila asumsi ini tidak berlaku maka pada proses pemilihan node yang akan disisipkan (langkah 2), nilai $Z_{11}(i, u, j)$ dan $Z_{12}(i, u, j)$ harus dikalikan dengan unit ongkos yang berlaku. Demikian juga dengan $\left(\begin{array}{ll}\lambda & d_{0 u}\end{array}\right)$ harus dikalikan dengan unit ongkos yang berlaku sebelum menghitung nilai $Z_{2}(i, u, j)$.

\section{DAFTAR PUSTAKA}

[1] Solomon, M.M. (1987), "Algorithms for the Vehicle Routing and Scheduling Problems with Time Window Constraints", Operations Research 35, 254-265.

[2] Solomon, M.M., E.K. Baker and J.R. Schaffer (1988), "Vehicle Routing and Scheduling Problems with Time Window Constraints: Efficient Implementations of Solution Improvement Procedures", in Vehicle Routing: Methods and Studies, B. Golden and A. Assad (eds), 85-106, Elsevier Science Publishers, Amsterdam.

[3] Solomon, M.M. and J. Desrosiers (1988), "Time Window Constrained Routing and Scheduling Problems", Transportation Science 22, 1-13. 
[4] Thangiah, S.R., I.H. Osman, R. Vinayagamoorthy and T. Sun (1995), "Algorithms for the Vehicle Routing Problems with Time Deadlines", American Journal of Mathematical and Management Sciences 13, 323-355.

[5] Ioannou, G., M. Kritikos and G. Prastacos (2001), "A Greedy LookAhead Heuristic for the Vehicle
Routing Problem with Time Windows", Journal of the Operational Research Society $52,523-537$.

[6] Ghiani, G., G. Laporte, and R. Musmanno (2004), "Introduction to Logistics Systems Planning and Control', John Wiley \& Sons Ltd. England, 273-279. 